\title{
Mundo Real e Mundo Ideal em Rousseau: da Necessidade da Ficção para Pensar o Político ${ }^{1}$ \\ REAL WORLD AND IDEAL WORLD IN ROUSSEAU: \\ ON THE NEED OF FICTION TO THINK ABOUT POLITICS
}

Maria Leone $e^{2}$

\begin{abstract}
RESUMO: A hipótese desenvolvida nos leva a confrontar três textos do corpus rousseauísta: o Segundo Discurso, Júlia ou A Nova Heloísa e o extrato do Primeiro Diálogo, em que há a ficção do mundo ideal, textos que, apesar do seu estatuto genérico diferente, estão em coerência e convergência teórica. Desejamos evidenciar um aspecto da unidade problemática do pensamento de Rousseau concernente à abordagem crítica da sociedade de seus contemporâneos e sua concepção do papel das Letras e dos Espetáculos. A preocupação do filósofo é de refundar a natureza humana, a fim de lançar as bases de uma nova organização social. Nessa empreitada, a ficção desempenha um papel crucial, o prefácio do Segundo Discurso o comprova: para bem conhecer o homem atual, deve-se supor o que ele náo é mais. O homem do estado de natureza, ser de ficção, cujas paixóes são retas e naturais, é o modelo teórico que reativa a sociedade dos seres ideais de Júlia. Dessa forma, a ficção é chamada a desempenhar um papel referencial fundamental para o pensamento social e político de Rousseau, aparecendo como um poderoso meio de ação sobre o público. $\mathrm{O}$ romance pode reeducar os povos corrompidos, pois, assim como o teatro, como denuncia a Carta a d'Alembert, possui os meios para perverter uma sociedade tida como virtuosa.
\end{abstract}

PALAVRAS-CHAVE: Ficção literária. Mundo ideal. Estética. Política.

Em que medida é possível considerar que a Nova Heloísa coloca em prática a lógica paradoxal do "remédio no mal", essencial à articulação da estética e do político em Rousseau? No Segundo Prefácio, o personagem "R", esquivando-se das acusaçôes sucessivas de seu interlocutor "N", lembra os prós e os contras do que é descrito como um verdadeiro sistema de pensamento, baseado na teoria paradoxal do uso da artificialidade, para combater e corrigir a desnaturação à qual o artifício social submeteu a natureza humana. $\mathrm{O}$ romance não deve ser lido como um resultado da inconsequência do autor da Carta a d'Alembert, mas como uma aplicação dos princípios do Prefácio de

\footnotetext{
${ }^{1}$ Tradução de Marisa Alves Vento - (doutora em Filosofia pela UNICAMP; professora no Instituto Federal de Educação, Ciência e Tecnologia de Goiás) - e-mail: ventomarisa@gmail.com - e Renato Moscateli (doutor em Filosofia pela UNICAMP; professor da Universidade Federal de Goiás e membro do Programa de Pós-Graduação em Filosofia da instituição) - e-mail: rmoscateli@hotmail. com - http://dx.doi.org/10.1590/S0101-31732015000400005

${ }^{2}$ Doutoranda em Literatura Francesa na Université Grenoble 3. Professora de Letras Modernas no Lycée Jean Perrin e na École Normale Supérieure - Lettres de Lyon. E-mail: maria.leone@free.fr.
} 
Narciso. A ficção romanesca encarna uma outra forma da renovação conceitual exposta na Carta a d'Alembert, renovação que o Colóquio organizado por Blaise Bachofen e Bruno Bernardi destacou: "[...] entre a política e a moral, a mediação estética é essencial” (2011, p. 7). A ficção, portanto, desempenha um papel fundamental na determinação e realização do novo ideal político que se desenvolve nos textos de Rousseau desde Segundo Discurso.

A hipótese que eu gostaria de desenvolver é a seguinte: na concepção de seu romance, Rousseau define o espaço da ficção de acordo com um modelo teórico, que os Diálogos formalizaram a posteriori, na ficção pedagógica do "mundo ideal", a qual se apresenta como um verdadeiro "dispositivo de ação" para o leitor. Esse dispositivo é atuante porque expôe uma matriz dinâmica em que se confrontam obstáculos e linhas de força. Relacionado à economia romanesca, ele destaca os níveis de significado da obra e, mais essencialmente, oferece ao leitor uma chave de leitura das relaçóes humanas, renovando completamente os dados psicológicos característicos da verossimilhança do universo ficcional (como Prévost e Richardson puderam, por exemplo, estabelecer), para delinear os princípios de uma sociedade moralmente regenerada suscetível de refundar o político.

A ficção, como Rousseau emprega em seu romance, não tem por objetivo corrigir o homem, apontando suas falhas, nem confrontá-lo com um modelo ético superior e inacessível. Ela se apresenta como radicalmente nova em seu funcionamento e em seu objetivo. Sobretudo em seu funcionamento, pois ela se enuncia segundo os princípios geométricos e dinâmicos descritos no Primeiro Diálogo. Esses princípios provavelmente têm sua origem no pensamento militar estratégico da época, universo que Rousseau pôde frequentar, graças ao seu tio engenheiro, ou no período em que ele escreveu o livro IV de suas Confissóes, onde evoca as lembranças de um Rousseau jovem, seguindo rumo a Paris e preparando-se para tornar-se um cadete. Esse modelo dinâmico e geométrico, o qual toma emprestado grande parte de suas regras da estratégia militar própria do seu século, permite o desenvolvimento de um quadro romanesco em que o motor da trama, a dinâmica da ação, náo mais se baseia em eventos e reviravoltas resultantes do confronto com um adversário identificado como "vil" e "mau". Nesse aspecto, Rousseau modifica os modelos românticos estabelecidos por Richardson e Prévost (em Clarissa e Cleveland, em particular), nos quais o principal motor da ação mobiliza os dados dinâmicos da traição e vilania dos personagens negativos, assimilados aos "perversos insensíveis", para confrontá-los à confiança e à inocência de 
personagens positivos assimilados aos "seres sensíveis". Nessa perspectiva, o "mundo ideal" do Primeiro Diálogo pode ser lido como uma inovação tanto no campo da antropologia - o que M. Rueff coloca em evidência ${ }^{3}$ - como no da ficção, considerado como uma criação artificial de universos reais possíveis e verossímeis psicologicamente. Em relação ao objetivo de tal universo romanesco, deve-se notar, mais uma vez, uma forma de renovação, já que Rousseau espera uma regeneração moral e política de seus leitores.

A leitura do romance deve desencadear no leitor um tipo de interrogação filosófica do qual Yannick Séité (2002) analisou uma das manifestações no discurso paratextual e autoral (ou pseudoautoral) das notas de Júlia, e que é irredutível ao simples entretenimento reflexivo e estético. Funcionamento e objetivo sendo concebidos como inerentes um ao outro, veremos como o "dispositivo de atuação" do "mundo ideal" reclama, por conseguinte, a regeneração ético-política do leitor.

Minha proposta está organizada em três momentos: considero, em primeiro lugar, a renovação romanesca e antropológica trazida pelo modelo dinâmico e geométrico do "mundo ideal", para, em seguida, identificar as perspectivas significativas abertas pela aplicação desse modelo à economia da obra e, finalmente, apreciar os níveis de realização dessa força atuante que constitui o dispositivo ficcional do "mundo ideal", ligado ao potencial de regeneração moral e política, o qual Rousseau confere ao seu romance.

\section{O MODELO DINÂMICO E GEOMÉTRICO DE UM “MUNDO IDEAL”}

No livro IV das Confissóes, Rousseau se descreve como um jovem exaltado, sonhando com a profissão militar vislumbrada por ele enquanto estava em Soleure, junto ao embaixador da França. Ele partiu a pé para Paris para se tornar cadete, a serviço do sobrinho do Sr. Godard, "coronel suíço que servia à França." O humor, o deboche divertido, até o ridículo são outros tantos toques mobilizados para esse retrato feito "à distância temporal", que parece enfatizar a incompatibilidade entre uma alma literária e sensível e a realidade projetada, gloriosa e radiante dos campos de batalha. O texto autobiográfico constrói claramente essa oposição:

Eu me inflamava tanto com essas loucuras que apenas via tropas, trincheiras, gabióes, baterias e eu no meio do fogo e da fumaça, dando tranquilamente

${ }^{3} \mathrm{Na}$ tese intitulada Anthropologie et poétique: la notion de modèle chez Jean-Jacques Rousseau, defendida em 2001, na Universidade de Sorbonne (Paris IV), e ainda não publicada. 
as minhas ordens, com os binóculos à mão. Mas quando eu passava pelos campos aprazíveis, onde eu via pequenos bosques e riachos, essas paisagens me faziam suspirar com pesar; eu sentia, em meio à minha glória, que meu coração não fora feito para tantos tumultos, e logo, sem saber como, eu me encontrava em meio aos meus adorados prados, renunciando, para sempre, aos trabalhos de Marte. (ROUSSEAU, 1959, p. 159).

O mundo da ação militar e o da sensibilidade literária aparecem no texto numa oposição, ao mesmo tempo, destacada e atenuada. $\mathrm{Na}$ verdade, o "tumulto" da batalha não tem nada a ver com o quadro idílico e rústico de natureza encantadora, mas a literatura preciosa pôde, no desdobramento de algumas de suas longas intrigas, mesclar, assim, o universo militar com as emoções amorosas vividas por entre "riachos", "bosques" e outros "prados" $\mathrm{O}$ estilo de Rousseau, nesse autorretrato burlesco, como um jovem "cabeça oca" se imaginando "marechal" 5 , toma emprestado, bem ironicamente, o estilo da literatura preciosa ${ }^{6}$ onde os heróis nobres, semelhantes aos que Rousseau sonhava ser - "[...] eu já me acreditava vestido em uniforme de oficial com uma bela pluma branca” - viviam de doces aventuras sob as mais estéticas paisagens naturais.

A oposição da literatura e da arte militar é, portanto, apenas superficial. O texto das Confissóes, escrito por Rousseau alguns anos após a conclusão de seu romance, indica uma familiaridade profunda entre arte da guerra e a da escrita. Um pouco mais tarde, no mesmo livro IV, essa conexáo reaparece explicitamente, quando Rousseau comenta uma pequena peça poética e satírica que ele produziu, para vingar-se da ganância e do desprezo Coronel Godard:

Esta pequena peça, mal feita, de fato, mas não insípida, e que anunciava um talento para a sátira, no entanto, é o único escrito satírico que saiu da minha pena. Eu tenho um coraçáo muito pouco rancoroso para me aproveitar desse talento; mas acho que podemos julgar por alguns escritos polêmicos, feitos de tempos em tempos em minha defesa, que se eu tivesse um humor combativo, meus agressores raramente provocariam risos às minhas custas. (ROUSSEAU, 1959, p. 162, grifos nossos).

\footnotetext{
${ }^{4}$ Sobretudo em Clélie, da Srta. de Scudéry, em que a intriga amorosa tem como pano de fundo os grandes feitos e os campos militares do exército romano.

${ }^{5}$ Náo sendo de origem nobre, durante sua breve carreira militar, Rousseau poderia, na melhor das hipóteses, se tornar capitão. A ênfase aqui, recai sobre a ironia da descrição.

${ }^{6} \mathrm{~A}$ "literatura preciosa" é uma corrente literária surgida na França do séc. XVII, cujas obras seguiam um refinado código sentimental e social elaborado nos salóes aristocráticos. Sua poesia e prosa caracterizavam-se por retratar o amor de uma forma altamente idealizada. O romance pastoral A Astreia, de Honoré d'Urfé (1607-1628), é um dos principais exemplares dessa corrente. (Nota dos tradutores).
} 
"Escritos polêmicos", "defesa", "humor combativo", "agressores", a literatura pode ser, a seu modo, uma arte de guerrear que Rousseau afirma saber dominar perfeitamente, quando necessário. A escritura e a estratégia militar têm uma base comum. O confronto de outros dois textos do corpus rousseauísta convida-nos a reavaliar a íntima conexão entre a arte literária e a da guerra. Os dois textos em questão são a Nova Heloísa e a "ficção educacional" do "mundo ideal", exposta no Primeiro Diálogo. A convergência entre os dois universos, o militar e o literário, nesses dois textos, implica uma reflexão sobre as questóes de estratégia e de teorização do movimento de elementos no interior de um sistema dinâmico. Em outras palavras, a ficção do "mundo ideal", a qual se apresenta na forma de uma geometrização dinâmica das relaçôes humanas, e a evoluçáo da arte estratégica militar no século XVIII rumo a uma teorização geométrica e abstrata das relaçôes de poder em jogo nos exércitos rivais ${ }^{7}$ lançam novas luzes nessa articulação entre o mundo das letras e o da guerra.

A grande transformação do pensamento estratégico militar, no século XVIII, consistiu numa transcrição abstrata e geométrica das forças militares no campo de batalha. Esse período deu origem a uma verdadeira "escola geométrica” que considerava consistir a estratégia militar na aplicação e no respeito das regras assimiladas a verdadeiros princípios geometrizantes ${ }^{8}$. Podemos, portanto, supor que a leitura geometrizante das relaçóes humanas que propôe a ficção do "mundo ideal" reatualiza, para Rousseau, a relação entre os mundos literário e militar. É, pois, com estas palavras que Rousseau descreve seu "mundo ideal", no início do Primeiro Diálogo:

Imaginemos um mundo ideal semelhante ao nosso, contudo, bem diferente. [...] Lá as paixôes são, como aqui, o móvel de toda ação. Porém, mais vivas, mais ardentes, ou apenas mais simples e mais puras, elas ganham, apenas por isso, um caráter muito diferente. Todos os primeiros movimentos da natureza são bons e corretos. Eles tendem tão diretamente quanto possível à nossa conservação e à nossa felicidade: mas táo logo faltem forças para seguir com determinação a sua primeira direção, eles se deixam dissuadir por mil obstáculos que os desviam de seu verdadeiro propósito e, tomando caminhos tortuosos, o homem esquece o seu primeiro destino. $\mathrm{O}$ erro

7 Sobre essa evolução que se realiza progressivamente, ao longo do século XVIII, cf. Franco Cardini (1992). Mais especificamente, sobre o papel decisivo que tiveram os escritos de Henri de Jomini (1779-1869), em relação à necessidade do recurso ao geometrismo, no pensamento estratégico militar, ver Christophe Wasinski (2010).

${ }^{8}$ Essa escola reúne notadamente, como observa C. Wasinski, Humphrey Lloyd (1718-1783), autor de uma obra amplamente difundida: Histoire de la guerre d'Allemagne pendant les années 1756 et suivantes, Paris: An XI, 1803, e Adam Heinrich Dietrich von Bülow (1757-1807), autor de Esprit du système de guerre moderne, Paris: Marchant, 1801. 
de julgamento e a força dos preconceitos contribuem muito para tal mudança; mas esse efeito vem, principalmente, da fraqueza da alma que, seguindo debilmente o impulso da natureza, se desvia pelo impacto com um obstáculo, tal como uma bola assume o ângulo de reflexão, ao passo que aquela que segue mais vigorosamente o seu curso não se desvia, mas, como uma bala de canhão, força o obstáculo ou se amortece e cai ao encontrá-lo. (ROUSSEAU, 1959, p. 668-669, grifos nossos).

Os princípios descritivos estabelecidos por esse texto são semelhantes aos mobilizados pela estratégia militar: as relações de força são traduzidas geometricamente ${ }^{9}$, a sociedade humana em questão é representada abstratamente, num sistema dinâmico, tomando emprestadas algumas de suas imagens da balística (a da bola tomando o ângulo de reflexão ou a da bala de canhão ${ }^{10}$ ).

Duas questóes surgem: em primeiro lugar, como o "mundo ideal" está relacionado ao de Clarens, no romance? Em segundo: como interpretar, no mundo da ficção, esse modelo provavelmente emprestado da estratégia militar da época?

Para responder à primeira questão, consideramos dois elementos como prova: a hipótese de uma sistematização a posteriori dos princípios que orientaram a invenção romanesca é baseada no fato de que o Primeiro Diálogo, assim como o Segundo Prefácio, faz do autor da Nova Heloísa um habitante do "mundo ideal". Além disso, a descrição do "mundo ideal”, a qual se estende ao longo de várias páginas, modela a paixão amorosa e o ciúme, colocando a evolução oposta dos sentimentos dos dois amantes em situação de rivalidade. A descrição do mais apaixonado dos dois caracteriza o comportamento de Saint-Preux ${ }^{11}$.

${ }^{9}$ No livro IV, na passagem citada, Rousseau expressou seus conhecimentos de geometria: "Eu tinha alguma noção de geometria". No livro VI, ele insiste na superioridade da geometria em relaçáo à álgebra: "Eu não gostava dessa maneira de proceder sem ver o que se faz, e me parecia que resolver um problema de geometria por meio de equações era tocar uma música girando uma manivela. A primeira vez que eu descobri, por meio do cálculo, que o quadrado de um binômio era composto do quadrado de cada uma de suas partes e do dobro da multiplicação de uma pela outra, apesar da correção da multiplicação, eu não quis acreditar em nada disso até que eu tivesse desenhado a figura. Não era que eu não tivesse um grande gosto pela álgebra considerando apenas a quantidade abstrata, mas, aplicada à extensão, eu queria ver a operação sobre as linhas, ou então eu nada compreendia” (1959, p. 238).

${ }^{10}$ É possível que Rousseau tivesse também em mente o texto de Voltaire sobre a morte de Turenne, atingido por uma bala de canháo.

11 "Dois amantes, um muito apaixonado, o outro muito morno, encontrarão, não obstante, um rival com a mesma impaciência, um por causa de seu amor, o outro por causa de seu amor próprio. Mas pode muito bem acontecer que o ódio do segundo, tornado sua paixão principal, sobreviva a seu amor e até mesmo aumente depois que este se extinguir. Ao passo que o primeiro, que só odeia porque ama, deixa de odiar seu rival tấo logo não o tema mais" (1959, p. 670). Desse modo, Saint- 
Quanto ao fato de saber por que o modelo do "mundo ideal" emprestaria seus princípios para a concepção geométrica da estratégia militar, isso nos leva a considerar a reapropriação e redefinição por Rousseau dos universos romanescos de Prévost e, especialmente, de Richardson. O Segundo Prefácio, a última nota do romance e o início do livro XI das Confissóes são esclarecedores sobre esse ponto: neles, Rousseau afirma o seu êxito na remoção radical de dois dos motores exclusivos da narrativa: o personagem do "perverso" e a desmultiplicação das aventuras. Com efeito, aprendemos nesses textos que Rousseau concebeu um universo romanesco em que a trama e suas reviravoltas são construídas de acordo com uma lógica nova e apurada, a qual não utiliza, em nenhum momento, o obstáculo eventual que constitui o opositor encarnado na personagem do "viláo", nem a renovaçáo do interesse por meio da encenação de múltiplas aventuras. ${ }^{12}$ Nessa perspectiva, o modelo geométrico específico da estratégia militar pode atuar como uma forma de "substituto". O sistema dinâmico da geometrização das relaçóes de força, em substituição aos princípios da dinâmica eventual que Rousseau rejeita.

Preux, uma vez reintegrado na sociedade íntima de Júlia, torna-se amigo tanto do marido dela, Wolmar, quando do pai dela, o barão d'Étange.

${ }^{12}$ Este é o conteúdo da nota final do romance: "Ao acabar de reler esta coletânea, eu creio ver por que seu interesse, por mais fraco que seja, é tâo agradável para mim e, penso, também o será para qualquer leitor de bom natural. É que, pelo menos, esse frágil interesse é puro e sem mescla de pesar; ele não é suscitado por perfídias, por crimes, nem misturado ao tormento do ódio. Eu não conseguiria conceber qual prazer se poderia ter em imaginar e compor o personagem de um celerado, em colocar-se no lugar dele enquanto o representamos, em emprestar-lhe o brilho mais impressionante. Lamento muito os autores de tantas tragédias cheias de horrores, que passam a vida fazer agir e falar pessoas que não podemos ouvir ou ver sem sofrer. Parece-me que deveríamos chorar ao sermos condenados a um trabalho tấo cruel; aqueles que fazem disso um divertimento devem ser muito inflamados de zelo pela utilidade pública. Quanto a mim, admiro sinceramente seus talentos e belos gênios, mas agradeço a Deus por não mos ter dado" (1961, p. 745). Lemos, no Segundo Prefácio: "Quanto ao interesse, ele é para todos, é nulo. Nenhuma má ação, nenhum homem mau que faça temer pelos bons". O início do livro XI das Confissóes faz o seguinte esclarecimento: "A coisa que menos vemos e que sempre tornará uma obra única é a simplicidade do assunto e a cadeia de interesse que, concentrado em três pessoas, mantém-se ao longo de seis volumes, sem episódio, sem aventura romanesca, sem malícia de qualquer tipo, seja nos personagens ou nas açôes. Diderot fez grandes elogios a Richardson pela variedade prodigiosa de seus quadros e pela multiplicidade de seus personagens. Richardson, de fato, possui o mérito de têl-los caracterizado muito bem. Porém, quanto ao seu número, trata-se de algo comum aos romancistas mais insípidos que compensam a esterilidade de suas ideias por meio de personagens e aventuras. É fácil despertar a atenção apresentando incessantemente eventos inéditos e novos rostos que passam como as figuras da lanterna mágica. Mas manter sempre essa atenção sobre os mesmos objetos e sem aventuras maravilhosas, isso certamente é mais difícil, e se, todas as coisas sendo iguais, a simplicidade do tema contribuir para a beleza da obra, os romances de Richardson, superior em tantas outras coisas, não poderiam, a esse respeito, igualar-se ao meu" (1951, p. 546-547). 
Vamos agora considerar o sentido que o romance adquire, quando o lemos a partir de princípios estratégicos e geométricos descritos no "mundo ideal".

\section{As PERSPECTIVAS SIGNIFICATIVAS ABERTAS PELA APLICAÇÁo DO MODELO DO “MUNDO IDEAL” À ECONOMIA DA OBRA}

Se traduzirmos o percurso de três dos personagens principais do romance - Júlia, Saint-Preux e Wolmar - sob a forma dos dados geométricos, chegaremos às seguintes hipóteses.

Júlia se encontra diante do obstáculo maior, isto é, o arranjo do seu casamento com o Sr. de Wolmar. Ela busca superar esse obstáculo "como uma bala de canhão", persuadindo-se da regeneração moral que lhe trará sua conversão ao templo, por meio do seu casamento; ela não consegue senão contorná-lo, pois seu amor por Saint-Preux a obriga a lutar continuamente contra seu desejo. Júlia conseguiu, até sua morte, manter artificialmente a retidão de sua trajetória. Em outras palavras, é impossível para aqueles que devem se conformar às convençôes sociais - nesse caso, a honra do barão d'Étange, com seus preconceitos - manterse em acordo com a natureza (todo impulso, toda paixão natural sendo por essência reta), senão artificialmente. A regra interior à qual a senhora de Wolmar se obriga é a expressão figurada desse artifício.

Saint-Preux não passa na prova do obstáculo. Ele "se amortece e cai ao encontrá-lo". Sua paixão natural o inclina para o objeto agora inacessível, ele cessa de agir. E recusa "o equivalente" que Júlia lhe propóe, a saber, o casamento com Clara, preferindo permanecer num estado de "aniquilamento" em que "tombou", como relata a sexta carta ${ }^{13}$. Saint-Preux não tem mais uma trajetória própria, ele vive à mercê do que o circunda ${ }^{14}$. Ele se reduz a seguir a trajetória que Júlia determina para ele, a da linha reta baseada na força interior, como mostra a oitava carta da sexta parte ${ }^{15}$; ou a que Wolmar quer lhe impor e cuja retidão seria garantida pelo redirecionamento de um impulso natural,

13 "Cara amiga, não abale as resoluçóes das quais depende o repouso de meus dias; não busque me retirar no aniquilamento onde caî" (1961, p. 681).

${ }^{14}$ Parte V, carta 2, de Saint-Preux a Milorde Eduardo: “[...] ao conviver com esses felizes esposos, sua ascendência me conquista e me toca insensivelmente, e meu coração se coloca, gradativamente, em uníssono com os deles, tal como a voz toma, sem pensarmos, o tom das pessoas com quem falamos" (1961, p. 527).

15 "É nessa delicadeza que sobrevive sempre ao verdadeiro amor, mais do que nas sutis distinçôes do Sr. de Wolmar, que é preciso buscar a razão dessa elevação de alma e dessa força interior que experimentamos um ao lado do outro, e que eu creio sentir assim como vós" (ROUSSEAU, 1961, p. 688). 
artificialmente obtido pela supressão do quadro passado de sua paixão. De fato, no romance, Wolmar aplica um método, a fim de curar Saint-Preux de sua paixão, substituindo um quadro por outro: a imagem de Júlia amante deve ser substituída pela imagem da senhora de Wolmar virtuosa.

Wolmar segue uma trajetória que náo resulta do ponto de vista em que a natureza o colocou: é um homem frio que ignora em si a força do sentimento e da piedade. O percurso de Wolmar é problemático: ele não tem por primeiro impulso as paixóes naturais, mas um apego profundo à ordem e à simetria ${ }^{16}$. Até o momento de sua amizade com o pai de Júlia, a trajetória de Wolmar era a da linha seccionada das paixóes sociais ${ }^{17}$. Seu encontro com Júlia produz uma confusão interior, um verdadeiro "choque" (para retomar a terminologia da ficção do "mundo ideal"), o qual revela o que ele nunca deixou e não deixará de ignorar: sua própria sensibilidade ${ }^{18}$.

Nessa geometrização figurada do espaço romanesco, Clarens surge como um sistema complexo de cruzamento de linhas de força, em que a linha reta é sonhada e constantemente projetada, em que a realidade dos caminhos interiores é a dos desvios e trilhas que se cruzam. A arquitetura do lugar, onde a simetria rigorosa dos edifícios responde à desmultiplicação das curvas e dobras do Eliseu, é uma simbolização topográfica. Clarens é um universo cartográfico e cartografado, como narram todas as cartas que, direta ou indiretamente, descrevem os lugares em que evolui a sociedade de "almas sensíveis". Esse apego ao contexto geográfico não é apenas a aplicação do princípio da verossimilhança, mesmo da realidade, capaz de transformar o "romance" em "testemunho autêntico". Parece que ele manifesta um dos níveis de realização do dispositivo eventual, o qual constitui o modelo geométrico dinâmico do "mundo ideal": o lugar é um elemento atuando no sistema de confrontação de forças presentes em Clarens. Tal espaço inclui os lugares proibidos ou

16 "Meu único princípio ativo é o gosto natural pela ordem, e o concurso bem combinado do jogo da fortuna com as açôes dos homens agrada-me exatamente como uma bela simetria em um quadro, ou como uma peça bem conduzida no teatro" (ROUSSEAU, 1961, p. 490-491).

17 "O coração sensível e grato desse bravo oficial começa desde então a me dar a melhor opinião da humanidade. Ele se uniu a mim por uma amizade à qual me era impossível recusar a minha, e nós não paramos de manter, desde essa época, ligaçōes que se tornaram mais estreitas com o passar dos dias. Eu aprendi, em minha nova condição [a de mercenário], que o interesse não é, como eu acreditava, o único móvel das açóes humanas e que, entre os inúmeros preconceitos que combatem a virtude, há também os que a favorecem" (ROUSSEAU, 1961, p. 491).

18 "Eu vim e vos vi, Júlia, e descobri que vosso pai me havia falado modestamente de vós. Vossos arrebatamentos, vossas lágrimas de alegria ao beijá-lo me deram a primeira, ou melhor, a única emoção que já experimentei em minha vida” (ROUSSEAU, 1961, p. 492). 
secretos (o quarto principal, o gabinete de Júlia, o bosque do primeiro beijo dos amantes) que constituem também obstáculos simbólicos suscetíveis de bloquear qualquer confronto, abismos onde as trajetórias possam se chocar. O território da Clarens pode ser apreendido como a projeção imaginária de um mapa do estado-maior, terreno cujas irregularidades e zonas sombrias ameaçam aniquilar as forças presentes.

A ação é compreensível graças às características do espaço no seio da qual ela se desenvolve, seja esse espaço externo, seja interno. O universo ficcional da Nova Heloísa é comparável a um sistema em movimento onde se enfrentam e se confrontam as forças convergentes ou opostas. Cada personagem é, em si mesmo, um campo de batalha, pois a memória, as camadas do desejo e a necessidade da vida em sociedade construíram individualidades complexas, cujos discursos e pensamentos são de mão-dupla e dissimulados, e raramente se enunciam com transparência. Pensemos no amor, constantemente reprimido e redirecionado, de Júlia e Saint-Preux, durante suas vidas em Clarens, ou nas contradiçóes que povoam Wolmar, ao abdicar da razáo, pelo menos em duas ocasióes ${ }^{19}$, diante da sensibilidade e cuja sabedoria, por vezes, toma ares de manipulação ${ }^{20}$. Esses personagens, eles mesmos definidos como linhas de forças complexas e em movimento, são regularmente levados a interagir uns com os outros. Na verdade, tal é a regra de Clarens: cada um vive sob o olhar dos outros, todos leem e "entreleem" suas cartas.

A ficção apresenta-se, por conseguinte, como um sistema movido pelos múltiplos confrontos das diversas forças presentes. Nisso, seu princípio eventual é comparável à economia de forças representadas pelo dispositivo estratégico militar, que considera as múltiplas configuraçôes das oposiçóes possíveis. Nessa perspectiva, o retrato moral de Júlia pode ser expresso em comparação com Germanicus, o general romano, tradicionalmente identificado com o herói amado e virtuoso. Assim, lemos esta observação de Saint-Preux sobre Júlia, no episódio da "matinée à Inglesa" na quinta parte da terceira carta: "Na questão da doença do rei da França e do apreço singular de seu povo, que jamais se igualaria ao dos romanos por Germanicus, ela fez algumas reflexôes sobre a natureza boa dessa nação doce e benevolente [...]

${ }^{19} \mathrm{O}$ encontro com Júlia e o retorno de Clara a Clarens, seguido de sua instalaçấo definitiva.

${ }^{20} \mathrm{O}$ que aparece na leitura da décima sétima carta da quarta parte, uma vez que Wolmar, por assim dizer, "organizou" a conversa a sós de Júlia e Saint-Preux, ao sair de Clarens voluntariamente, num momento "crítico" da evolução dos sentimentos dos amantes, os quais se acreditavam curados sem está-lo. O bilhete que Júlia endereça a seu esposo é testemunha disso: “[...] vós desfrutais duramente da virtude de vossa mulher". 
acrescentando que, do posto supremo, ela apenas invejava o prazer de se fazer amar" (ROUSSEAU, 1961, p. 559). Ainda nessa perspectiva, a exposição, no Livro IV das Confissóes, da miopia do "Marechal Rousseau", inspecionando a zona de combate com "o binóculo à máo", se desenvolveria como uma reescritura burlesca e irônica do extrato da vigésima sexta carta, na primeira parte do romance, onde Saint-Preux observa pelo telescópio a casa de Júlia. A cena ilustra duplamente a colocação em prática do "dispositivo ficcional dinâmico e estratégico", relacionado aos dois espaços concretos e simbólicos de Clarens e do corpo, irrepresentável e constantemente desejado, de Júlia.

A aplicação dos princípios estratégicos e dinâmicos que constituem o "mundo ideal", no romance, conduz a lê-lo como um "dispositivo" cujo funcionamento toma emprestado os dados geométricos da estratégia militar e que, constituindo o motor da ficção, deve ter um "impacto" moral e político sobre os leitores. Interessamo-nos agora pelas condiçóes suscetíveis de organizar o efeito sobre os leitores desse arranjo romanesco.

\section{O DISPOSITIVO FICCIONAL DO “MUNDO IDEAL” E A REGENERAÇÃo MORAL E POLÍTICA DOS LEITORES}

Em que medida a aplicação do sistema dinâmico do "mundo ideal" à ficção da Nova Heloísa conduz a ler o romance como um dispositivo que atua moralmente sobre os leitores? Para responder a essa questão, é preciso considerar o duplo movimento reflexivo e crítico que levou à substituição de um modelo estratégico dinâmico pela lógica eventual fundada sobre a estética do "personagem negativo", e as múltiplas reviravoltas engendradas por esse obstáculo narrativo.

Primeiramente, se confrontarmos o romance com os princípios expostos na Carta a d'Alembert, como o Prefácio dialogado convida a fazê-lo, esse "dispositivo narrativo", próprio do mundo ideal, surge como um emprego paradoxal e experimental de uma das principais modalidades de expressão do poder que a ficção possui, pois passa a representar o amor, ganha adesão e dirige as açóes dos espectadores. A crítica que Rousseau faz, na Carta a d'Alembert, das tragédias de Berenice e de Zaira é esclarecedora sobre esse ponto: não somente a pintura da paixão, atingindo a perfeição nessas duas peças, supera qualquer moral - "[...] tanto é verdade, que os dois quadros do amor causam mais impressão do que as máximas de sabedoria” (ROUSSEAU, 1995, p. 50) -, mas também garante a articulação tão problemática entre o universo da representação 
ficcional, o qual pertence ao autor, e o da ação real, que pertence ao espectador. De fato, Rousseau enfatiza, sobre a tragédia de Voltaire:

Eu queria ser capaz de encontrar alguém, homem ou mulher, que ousasse se vangloriar de sair de uma representaçáo de Zaira bem prevenido contra o amor. Quanto a mim, eu creio ouvir cada espectador dizer para si no final da tragédia: Ah! Deem-me uma Zaira, eu darei um jeito de não matá-la.

Se a ficção pode obter um controle sobre o mundo real, é segundo uma catarse que vem abolir a ruptura entre o lugar do espectador e o do ator. Apenas a representação da paixão amorosa garante essa continuidade, a representação da virtude reintroduziu o processo de ruptura (quem é o espectador, não será o ator).

Nessa perspectiva, o "dispositivo" do mundo ideal aparece como uma verdadeira experiência, cujo desafio moral é chegar ao leitor e ter um efeito em seu posicionamento social, moral e político. $\mathrm{O}$ romance, onde toda a dinâmica de acontecimentos se centra exclusivamente no desenvolvimento complexo das paixôes positivas e da sensibilidade amorosa e afetiva dos personagens, é um tipo de princípio pedagógico ativo, cuja leitura é suscetível de produzir a regeneração moral em cada ser. Tanto quanto os leitores, afetados pela delicadeza e pelo poder do sentimento no romance, possam se expressar, como os espectadores saídos da tragédia de Voltaire: "Ah! Deem-me uma Júlia, eu darei um jeito de não matá-la”. O que, se for o caso, significaria que a realidade corrige e vai além do modelo de perfeição mostrado na ficção e, portanto, implicaria que o romance é "remédio" para a degeneração social.

Em segundo lugar, se considerarmos o princípio que rege a economia interna desse "dispositivo geométrico e estratégico" atuante no romance, é forçoso constatar que ele se apresenta como uma estrutura aberta por sua tripla capacidade de evoluir, de se modificar em vista de um fim, e exteriorizar a questão da sua atualização. A capacidade de evoluir e mudar em vista de um fim ${ }^{21}$ remete à complexidade do sistema de Clarens, onde cada fenômeno da narrativa (personagem, ação, lugar) é considerado como um elemento interativo com todos os outros. A essa dimensão dinâmica se acrescenta a que

${ }^{21}$ Bernard Vouilloux salienta que essa característica dinâmica e teleológica distingue o "dispositivo" da "estrutura", lembrando as análises esclarecedoras de Lyotard, o qual afirma que a oposição entre essas duas noçóes é mais o resultado de um confronto de "pontos de vista teóricos" do que de uma realidade objetiva: a teoria do dispositivo denota uma ruptura, na história do pensamento, com a teoria estruturalista. Cf. "Du dispositif”, na coletânea organizada por Philippe Ortel (2008). 
mencionamos brevemente, na introdução, do discurso autoral e pseudoautoral do autor. Essa segunda dimensão ${ }^{22}$ inscreve o dispositivo da obra em uma "transformação" constantemente reorientada pelas perspectivas interpretativas do leitor. Finalmente, a questão da exteriorização do dispositivo do "mundo ideal" supóe que, assim como os padróes estratégicos militares que geometrizam as relaçôes de força presentes num campo de batalha virtual só encontram o seu sentido na sua atualização sobre um terreno concreto, do mesmo modo, o modelo teórico do mundo ideal apenas encontra o seu sentido no confronto com um universo humano e social real e resistente.

De acordo com este último ponto de vista, o efeito da Nova Heloísa poderia ser o de projetar em seus leitores e no seio da organizaçâo social uma "alteridade moral", questáo que o Segundo Discurso tinha levantado. O mundo moral e social produzido pela leitura da Nova Heloísa integraria esse dado psicológico característico dos habitantes do "mundo ideal" do Primeiro Diálogo:

O crime em si não é estranho para eles, uma vez que ele é das situaçóes deploráveis em que a maior virtude é apenas suficiente para se defender e que forçam ao mal o homem fraco, apesar de seu coração: mas a intenção expressa de prejudicar, o ódio venenoso, a inveja, a escuridáo, a traição, o engano são desconhecidos, muitas vezes vemos ali os culpados, nunca vemos um viláo. (ROUSSEAU, 1959, p. 668).

O crime permanece, mas a vilania e a intenção de prejudicar desaparecem. O paradoxo da obra literária agindo como "um remédio no mal" está concluído: esse estado social "corrigido" evoca aquele da "era das cabanas", no Segundo Discurso, onde as ciências e as artes, em seus inícios, são chamadas a não se desenvolverem, a fim de que esteja assegurado o equilíbrio feliz dessa sociedade primitiva. O romance produz o que deve destruí-lo. A Nova Heloísa aparece no século XVIII como um romance com as formas reflexivas mais paradoxais, uma vez que ele veicula, ao mesmo tempo, o princípio de sua reabilitação moral e o da sua destruição teórica.

${ }^{22}$ Como Séité (2002) a desenvolve. 
LEONE, Maria. Real world and ideal world in Rousseau: on the need of fiction to think about politics. Trans/Form/Ação, Marília, v. 38, p. 43-56, 2015. Edição Especial.

\begin{abstract}
ABSTRAC: The hypothesis that we will develop leads us to confront three texts of Rousseau's corpus: the Second Discourse, Julie, and the extract of the First Dialogue that speaks of the pedagogical fiction of the ideal world. These three texts, despite their different types, are theoretically coherent and convergent. We intend to highlight an aspect of the problematic unity of Rousseau's thought, an aspect which concerns his contemporaries' critical approach to society and Rousseau's conception of the role of letters and spectacles. Rousseau's concern is to refound human nature in order to lay the basis of a new social organization. In this effort, fiction plays a decisive role, as the preface to the Second Discourse affirms: in order to know modern man, we must consider a hypothesis about what he no longer is. Man in the state of nature, a fictional being whose passions are right and natural, is the theoretical model that reactivates the society of ideal beings in Julie. For Rousseau, fiction is called upon to play a fundamental referential role for social and political thought, and it appears as a powerful means of action on the public. The novel can reeducate depraved peoples, because, like the theater (as pointed out in the Letter to d'Alembert), it also has the means to pervert a so-called virtuous society.
\end{abstract}

KEYWORDS: Literary fiction. Ideal world. Aesthetics. Politics.

\title{
REFERÊNCIAS
}

BACHOFEN, Blaise; BERNARDI, Bruno (Orgs.). Rousseau, politique et esthétique: sur la Lettre à d'Alembert. Lyon: ENS Éditions, 2011.

CARDINI, Franco. La culture de la guerre. Paris: Gallimard, 1992.

ORTEL, Philippe (Org.). Discours, image, dispositif, penser la représentation II. Paris: L'Harmattan, 2008.

ROUSSEAU, J.-J. Euvres complètes. Paris: Gallimard, 1959. v. 1.

. Euvres complètes. Paris: Gallimard, 1961. v. 2.

. Euvres complètes. Paris: Gallimard, 1995. v. 5.

SÉITÉ, Yannick. Du livre au lire: la Nouvelle Héloïse, roman des lumières. Paris: Champion, 2002.

WASINSKI, Christophe. Rendre la guerre possible: la construction du sens commun stratégique. Bruxelas: Peter Lang, 2010.

Recebido / Received: 15/04/2015

Aprovado / Approved: 24/06/2015 